\title{
Big Data and College English Teaching Informationization-How to Reform the College English Teaching in the Era of Big Data
}

\author{
Yunhong Hou \\ Department of College English, School of Foreign Languages, Northeast Dianli University, Jilin, 132012, China
}

\begin{abstract}
Big data is the source of creative thinking, broad cognition and creation of new values. The technology revolution makes us living in the age surrounded by the explosion of geometric level data, the era of big data. Promoting the reform of college English, college English teaching has an urge to set a college English education informationization construction to deal with the opportunities and challenges and adapt to the new way of learning.
\end{abstract}

Keywords-big data; college English reform; college English education informationization.

\section{INTRODUCTION}

Big data era has come, the individual, as the main body of data production and circulation, needs big data when they are learning English. For example they continuously transfer and accumulation their data through the Internet, mobile phones, tablets, PCs and other equipment. Either in the school English class or on the English learning website as well as through the channels such as we chat information downloads, teacher-student interactions and the interaction between learners, etc. All these data will be stored in the corners of the world. How to adapt to the changes and reform college English teaching in the big data era is the strategic issues of college English instructors and requires deep inflection and considerable social practices.

There is no uniform definition for big data,, Victor Mayer-Schonberger pointed out that the core of the big data is prediction. He thinks that we can analyze more data in the era of big data, even can handle all data associated with a particular phenomenon sometimes rather than rely on random sampling. Secondly, in the era of big data there is so much data available for study, hence we are no longer keen on the pursuit of accuracy. Finally, in the era of big data people change from the causality of series thinking into the correlation between the parallel thinking. They no longer ask why, but find out what it is.

Zhou Tao (2013) said the characteristics of big data are big scales, high values, cross reuses and visible holography. He noted that the last two features embody that the big data has not only the progress in quantity, but also has a qualitative leap, because of the organization and application form of the big data in the last two characteristics is completely different as before.

In a word, big data is far huger than previous data on the scale, and has maintained rapid growth. The era of big data calls not for a random sample, but all the data. And it does not care about accuracy, but blending, not causation, but correlation between issues. Big data together with intelligent manufacturing, wireless internet revolution is referred to as one of the three major technological changes leading to the future prosperity.

\section{THE BIG DATA AND COLLEGE ENGLISH EDUCATION INFORMATIONIZATION CONSTRUCTION}

In nearly a decade the college English teaching has close connection with modern information technology. Based on computer network the classroom college English teaching model has widely applied throughout the country. Therefore the overall college English teaching level has been improved. The information data in the process of college English education grows in the geometric times. And the current college English information constructions are faced with the problem that how to realize the integration of the existing system and to make information system better able to cope with changes to meet the needs of the future.

\section{A. The college English education informationization construction situation}

Since the late 1990s China began to implement the strategy of education informationization. The education informationization is the application of information technology actively in all aspects of education and teaching guided by the advanced education thought to achieve the further development and widely use of information resources. It will cultivate innovative talents who is capable of handling the problems in the information society with the goal of accelerating the modernization of education system engineering. College English education informationization construction has transferred from the original single application, infrastructure and base build work to the application of the digital campus network construction, from the preliminary construction of campus network to the construction of digital resources emphasizing the application of system integration.

By the end of 2008, China has built more than 3000 university campus network. The college English education information resources construction has been improved dramatically both in quantity and quality. College English education resources construction is gradually perfect in China from the early material construction and the resources management platform construction to the resources application platform construction. At present a wide variety of online education resources, such as multimedia course 
wares, the English learning websites for secondary teachers' classroom teaching as well as for students' autonomous learning; There are courses to support the whole process of learning online course and a professional resource; There are a lot of online schools offering online remote teaching and counseling information, etc. Furthermore there is basic education resource pool, the fine course resource of higher education, the national vocational education corpus at all levels of all effective education resources construction. It has initially formed the effective mechanism of resource construction.

\section{B. Big data's application in college English education informationization}

This study takes the experience college English teaching model as an example by the integration of the teaching mode of the data with the goal of helping college English teachers and students make full uses of teaching and learning resources. Experiential informationization of college English teaching model refers to the students learn by themselves in extra-curricular network learning. There students choose what to learn by interests and to ask questions through the electronic bulletin board, BBS, chat rooms, message board posts, blogs, E-mails and other forms of interaction with people who are interested in their issues all over the extensive and in-depth discussion; furthermore, students can utilize search engines such as Google and Baidu and the tutors network rooms to find the answer to the question. The role of teachers mainly reflected in the management of network autonomous learning and the guidance of students learning, and make assessments in classroom of students' autonomous learning. The figure one is the college English teaching model of informationization.

When teachers found some of the data information was repeatedly browsed and clicked in the network autonomous learning after class, they usually realized immediately this can be a difficulty for students to master the knowledge. Hence they can adjust the worksheets. While the big data generalized by online simulation test can be used in the analysis and unified the situation of either a student or a group of students' grasp of different knowledge. As one subject is frequently done wrongly by the target individuals or groups, the online system will appear constantly the knowledge related to the topic in order to improve their weak points and consolidate their learning. This is not "cheating", instead it is to strengthen the understanding of knowledge.

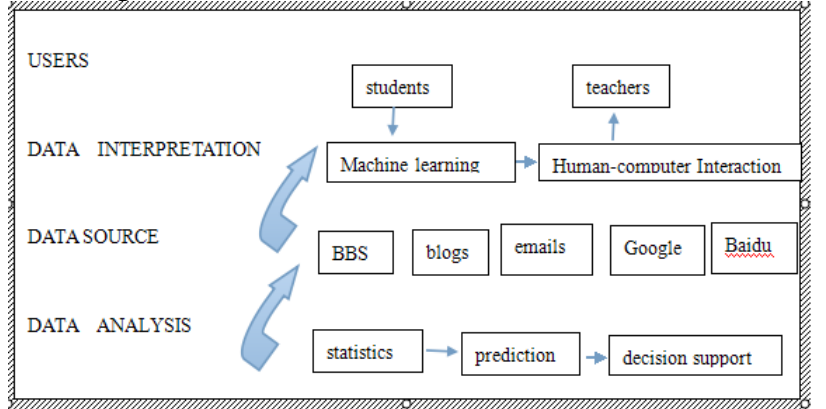

Figure 1. One: the college English teaching model of informationization
All in all, the analysis of big data is beneficial to teachers, students and administrators. They can choose services and achieve progresses and in the end the students' English capabilities are improved overall. During the process of college English teaching and learning there appears vast amounts of linguistic data. So teachers should guide students to scrutinize the data, which to some extent has tempered students' ability of observation and generalization as well as the ability for the professional development of college students.

\section{THE BIG DATA AND COLLEGE ENGLISH TEACHING REFORM}

There is a huge advantage of application of big data to foreign language teaching. Therefore the college English teaching reform must stick to the data informationization by scientifically integrating data information and foreign language teaching as a basic strategy. And it is a precondition for college English teaching reform.

\section{A. The big data and college English teaching reform informationization construction}

College English teaching reform is in the process of informationization, however too many funds have been pumped into the hardware facilities, which to a certain extent has promoted the development of education informationization, but in the real teaching and learning practice, there is hardly any funds that be used to software. And the lack of qualified soft wares makes it's harder to meet the requirements of the development of education informationization.

The other phenomenon is that there is a large number of idle, low utilization rate of resources in many colleges and universities. The contradiction is prominent in development and utilization of resources. College English teaching reform urges the balance between the investment proportion of the hardware and software. The application of information resources should lay particular stress on software investments at digital campus construction stage. The investment proportion between hardware and software should be around 3:7.Institutions should reasonably allocate software and hardware investment according to their own situation.

\section{B. Big data and college English teachers' development}

The current college English teaching has changed in the aspects of educational thoughts, ideas, contents as well as teaching methods in the big data era. To realize the popularization of big data and application in information technology in teaching, it's essential to build up a large number of qualified talents who have higher information literacy. First and foremost, universities should strengthen the cultivation of the professional and technical personnel and help them to quickly master the modern information theory and information technology as well as build a strong sense of responsibility, which ables them to satisfy the needs of the informationization construction, to ensure the reasonable design and scientific operation of information system; In addition it's significant to strengthen the 
leadership, management and teacher's information skills training, especially the innovation of ideological concept. Information skills training is the fundamental, and the innovation of ideological concept is the core.

College teachers should highlight the importance of information technology in the modern society, especially in the field of education and should realize the necessity of the application of information technology in the subject teaching with a scientific and new concept of education based on the modern education technology.

\section{CONCLUSIONS}

In the process of college English teaching reform, multimedia devices came into the college English classroom. Teachers choose the material from a vast data as a source of classroom input. They tend to find a huge amount of information and consequently increase the difficulty of their choices and raise teachers' workload. Therefore, teachers should learn how to reasonably choose what they need in a large amount of data.

In a word, it's highly recommended that the big data ,as the dominant factor, play a leading role in the college English teaching reform which will make an informationization class to optimize the classroom structure and function in the era of big data. At the practice level, foreign language teaching personnels should pay attention to the innovation of college English teaching ideas by ways of establishing classified curriculum system and the hierarchical classification system to build a data information multiple interactive classroom environment. Besides they should focus on improving the data information technology literacy to provide three-dimensional teaching resources as well as using environment-friendly teaching methods. html.2013
Hence they are able to develop equal and harmonious relationship between teachers and students and build multivariate evaluation system by scrutinizing the data collected in and out classroom.

\section{REFERENCES}

[1] Meng Xiaofeng and Ci Xiang Big Data Management:Concepts,Techniques and Challenges Journal of Computer Research and Development[J]. 2013 (1)

[2] Duncan J. Watts. THE "NEW" SCIENCE OF NETWORKS[J]. Annual Review of Sociology . 2004

[3] Katherine Faust,John Skvoretz. Comparing Networks Across Space and Time, Size and Species[J]. Sociological Methodology . 2002 (1)

[4] Doug Schuler. Social computing[J]. Communications of the ACM . 1994 (1)

[5] Chad A. Steed,Daniel M. Ricciuto,Galen Shipman,Brian Smith,Peter E. Thornton,Dali Wang,Xiaoying Shi,Dean N. Williams. Big data visual analytics for exploratory earth system simulation analysis[J]. Computers and Geosciences,2013,61

[6] Cristina L. Abad,Mindi Yuan,Chris X. Cai,Yi Lu,Nathan Roberts, Roy H. Campbell. Generating request streams on Big Data using clustered renewal processes[J]. Performance Evaluation,2013(8)

[7] C. Dobre,F. Xhafa. Intelligent services for Big Data science[J]. Future Generation Computer Systems,2013(7)

[8] Aniello Castiglione,Marco Gribaudo,Mauro Iacono,Francesco Palmieri. Exploiting mean field analysis to model performances of big data architectures[J]. Future Generation Computer Systems,2013(7)

[9] Daewoo Lee,Jin-Soo Kim,Seungryoul Maeng. Large-scale incremental processing with MapReduce[J]. Future Generation Computer Systems,2013(9)

[10] Victor Mayer-Schonberger, Kenneth Cukier.Big Data:A Revolution That Will Transform How We Live,Work and Think [M].HanZhou:ZheJiang People Publishing House,2013

[11] Zhoutao.http://blog.sciencenet.cn/blog-3075-603325. 